\title{
ÑANDE REKO ARANDU: memória viva guarani. Direção geral: Antônio Mauríicio Fonseca. Gravação: José Henrique Mano Penna. Duração: $73: 39$ min. CD MGV 2001.13326/98*
}

\author{
Deise Lucy Oliveira Montardo** \\ Universidade de São Paulo - Brasil
}

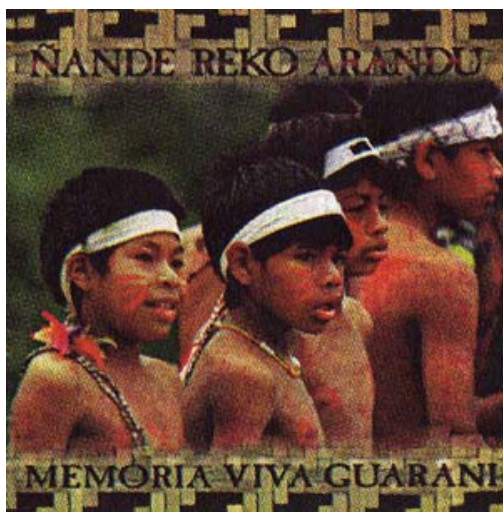

Este belo e emocionante CD contém 15 faixas, das quais as quatorze primeiras são exemplares do repertório de canções infantis e a última do repertório de xondaro (dança/luta) executadas pelos Guarani Mbya e Nhandeva das aldeias Rio Silveira (São Sebastião-SP), Sapucai (Angra dos Reis-RJ), Morro da Saudade (Parelheiros-SP) e Jaexaá Porã (Ubatuba-SP). O encarte que acompanha o CD traz a ficha técnica de todos os participantes, as letras das canções em

Guarani, suas traduções para o Português, ilustrações fotográficas das gravações e de momentos cotidianos das aldeias, desenhos infantis e um depoimento muito esclarecedor de um dos idealizadores do CD, o guarani Timóteo Verá Popyguá.

* Realização: Comunidade Solidária/ Interlocução São Paulo, Associação Indígena Tembiguai, Associação Indígena da Aldeia Morro da Saudade, Associação Indígena da Aldeia Rio Silveira e Associação Comunitária Indígena do Bracuí-Acibra. O processo de produção do $\mathrm{CD}$, feito sob patrocínio da Caixa Econômica Federal e Secretaria de Estado da Cultura de SP, está possibilitando que toda a renda advinda da sua comercialização seja revertida para as comunidades que dele participaram. Informações: (011) 8208274 e 929322030.

** Doutoranda em Antropologia Social. 
As quinze faixas que compõem o CD foram selecionadas pelos Guarani em um processo que se estendeu por dois anos e que contou com quatro pré-gravações realizadas em cada uma das aldeias, culminando com a gravação final, realizada na aldeia de Ubatuba, onde se reuniram cerca de 180 participantes, somadas as crianças, cantoras, e os instrumentistas. Este evento é narrado no encarte como um momento marcante de sentimentos de contato, união e força não apenas entre as quatro aldeias presentes mas entre todas as aldeias.

A opção tomada pela produção, de dar ao encarte exclusividade à voz Guarani, pode, por um lado, deixar alguns ouvintes curiosos acerca de informações tais como quem são os Guarani, quantos são, a que tronco linguístico sua língua está filiada, ${ }^{1}$ ou mesmo o material com o que são confeccionados os instrumentos executados nas canções gravadas, ${ }^{2}$ questões que seriam respondidas se o texto fosse feito por um etnomusicólogo ou antropólogo.

Por outro lado, o depoimento que compõe o encarte do CD responde algumas das perguntas que me fiz, enquanto pesquisadora da música Guarani, quando soube de sua produção. Uma delas diz respeito ao fato dos Guarani terem mantido uma certa reserva quanto a divulgação de seus cantos por estarem neles implicados aspectos cosmológicos, e por conseguinte religiosos, de sua cultura. Sob o sub-título "Segredo e Revelação" Timóteo Verá responde que "nós [eles] não temos mais jeito de esconder. Quando você não mostra, o povo branco fala que não tem mais cultura, não tem tradição. E, de repente, você mostra e você é valorizado. Através do CD todo mundo vai ver que o Guarani tem isso, Guarani existe. Vai existir. A música fala isso". Esta postura é representativa de uma estratégia política de apropriação do conceito de cultura, e da sua manutenção como patrimônio, que vem sendo utilizada por vários povos indígenas.

\footnotetext{
1 Os Guarani são os povos indígenas falantes de Guarani, língua da família lingüística Tupi-Guarani, Tronco Tupi. Quando os europeus aportaram neste continente os Guarani ocupavam extensos territórios nas bacias do Paraguai, Paraná, Uruguai e Costa Atlântica Meridional, o que hoje são partes dos Estados de Mato Grosso do Sul, São Paulo, Paraná, Santa Catarina e Rio Grande do Sul, no Brasil; e de Departamentos do Paraguai, Argentina e Uruguai. A população dos três subgrupos Guarani que habitam no Brasil atualmente é estimada em cerca de 40000 pessoas.

2 Os instrumentos com os quais são executadas as canções são o angu'apu (tambor feito com corpo de madeira e cobertura de couro de animais, tais como a cotia), mbaraka mirim (chocalho feito com cabaça, Lagenaria sp, contendo sementes), popygua (duas varas de madeira guajuvira, Coccoloba martii, amarradas uma na outra em uma das pontas), ravé (rabeca com três cordas) e mbaraka (violão com cinco cordas).
}

Horizontes Antropológicos, Porto Alegre, ano 5, n. 11, p. 203-205, out. 1999 
Uma outra questão que sempre aparece quando se fala na música Guarani refere-se ao uso, por parte destes, de instrumentos de corda, que teriam sido trazidos pelos europeus. A esse respeito Timóteo argumenta que o Guarani sempre utilizou instrumentos. "Eles utilizavam o violão, feito de casca de tatu... Os Guarani já tinham. Antes, muito antes dos jesuítas. Muito antes da invasão dos portugueses. Eles já tinham. E aliás, a afinação, eles já tinham a própria dos guarani. E rabeca também, já tinha a afinação. O guarani já tinha seu próprio violãozinho com 5 cordas representando Tupã, Kuaray, Karaí, Jakairá, Tupã Mirim [Deuses do Panteão Guarani].” Este depoimento denuncia o quanto é equivocada a noção, muito corrente, de que existiria uma cultura "pura" com os "seus" instrumentos, quando a prática humana é a da comunicação e da troca e que o interessante são os significados que estes vão tomando em cada contexto, mais do que sua "origem".

As canções que estão registradas no $\mathrm{CD}$ representam uma pequena parte de um repertório extenso de práticas musicais que incluem coreografias e, o que gostaria de salientar aqui, de práticas musicais cotidianas que preparam as crianças para o mundo, ou, em termos antropológicos, constróem a pessoa Guarani.

O xondaro apresentado na última faixa também, é apenas um, entre uma variedade grande de um gênero músico-coreográfico que corresponde ao que conhecemos como arte marcial. Nas palavras de Timóteo: "Esta dança tem a ver como uma defesa. Faz parte do dia-a-dia da aldeia guarani. No final do dia sempre tem a dança do Xondaro. O menino começa a dançar, começa a freqüentar esta dança. Ele tem seu próprio equilíbrio no seu próprio corpo." Ele continua, comentando que hoje usam o xondaro para desviar, para dançar, para ter equilíbrio e saúde, e que o Xondaro é preparado, pelo mestre xondaro para ser guerreiro.

O fazer musical como atividade cotidiana e essencialmente coletiva ajuda a criar não apenas o ser Guarani, mas cria também as suas redes de comunicação com os deuses, com outras aldeias e mais que isto, propicia a continuidade e a saúde da terra e da vida na terra. Lembra Timóteo que "tem a hora que a gente pode chorar, tem a hora que você pode rir, todos temos esses sentimentos através da música" e propõem em seu discurso pacifista "Paz mundial entre os povos. Que se crie uma aliança através dessa música.” 